Revised Draft

October 22, 2007

\title{
The Economics of Tuition and Fees in American Higher Education
}

by

\section{Ronald G. Ehrenberg*}

(Forthcoming in the International Encyclopedia of Education, 3rd edition)

* Irving M. Ives Professor of Industrial and Labor Relation and Economics at Cornell University and Director of the Cornell Higher Education Research Institute

Address:

ILR-Cornell University

385 Ives Hall East

Ithaca, NY 14853-3901

rge2@cornell.edu 


\begin{abstract}
This paper provides an introduction to the economics of tuition and fees in American Higher Education. It summarizes data on undergraduate tuition and fee levels in public and private institutions, discusses the forms of financial assistance that students receive, and provides explanations for why tuition and fees for undergraduate students in both private and public higher education institutions in the United States have increased, on average, by 2 to 3.5 percentage points a year more than the rate of increase in consumer prices. Finally, it briefly addresses tuition and fees in graduate professional and doctoral programs in the United States.
\end{abstract}

\title{
Key Words
}

Faculty productivity, financial aid, tuition and fees, tuition discount rate, U.S. News \& World Report rankings, Winner-take-all society 


\section{Introduction}

The American higher education system is a highly decentralized one. There are over 4,200 degree granting institutions in the United States. While the majority of institutions are private not for profits, about two thirds of all undergraduate students enrolled in four-year colleges attend public institutions; this share rises to about fourfifths once one adds in the students enrolled in two year colleges, which are predominately public institutions. A small but growing share of students are enrolled in private for profit degree granting institutions

For a number of years the College Board has been collecting data on tuition and fees and publishing it in annual volume Trends in College Pricing. In 2007-2008, the average tuition and fees at two-year public institutions, four-year publics and four-year privates were $\$ 2,361, \$ 6,185$ and $\$ 23,712$, respectively. The figures for public institutions are for students who reside in the same state as the institution is located; students from out-of-state and foreign countries are charged higher levels of tuition at the publics. The average public four-year out-of-state tuition and fees was $\$ 16,640$ that year. These averages mask considerable variation in the tuition and fees that students pay to attend both public and private institutions. For example, in 2007-2008 about 19\% of the students attending private four-year institutions faced tuition and fees that were over $\$ 33,000$, while almost $18 \%$ faced tuition and fees that were less than $\$ 15,000$. Similarly, while $45 \%$ of the in-state and out-of-state students attending public four-year institutions faced tuition and fee levels that were less than $\$ 6,000,13 \%$ faced tuition and fee levels that were more than $\$ 12,000$. 
It is important to stress that an institution's tuition and fee level does not reflect the full cost that institution incurs in educating undergraduate students. Gordon Winston from Williams College has very carefully documented that no undergraduate student at a public or private non-profit college or university (including those who receive no financial aid) pays the full cost of his or her education because of subsidies that are provided to them. In private higher education these subsidies come from income that the endowments of the university provide, from annual giving streams to the institutions provided by alumni, foundations, corporations and other donors, and from the value of the services of the buildings on campus that were constructed using funds from external donors. In public higher education, these subsidies come from all of the previous sources, as well as from current state appropriations and previous state appropriations for buildings and capital equipment. For future reference, it is important to note that Winston has also documented that the subsidies students receive are largest in absolute value at the nation's most selective (in terms of admission standards) and wealthiest private colleges and universities.

An institution's tuition and fee level also overstates the costs that many student incur to attend the institution because of financial aid provided to students by the federal government, state governments, the institutions themselves, and private donors. At the federal level, aid currently takes the form of grant aid for students from lower and lowermiddle income families, subsidized loans for students from lower and middle income families, and tax credits. A number of states have grant aid programs for students who reside in their state and attend colleges within the state. Sometimes these grant programs are restricted to students attending public colleges in the state. Depending upon the state, 
these grant programs may be either need-based or merit-based; an example of the latter is the Georgia Hope Scholarship program. A number of states also have special scholarship programs or loan forgiveness programs for students who are employed in the state after graduation in relatively low-paying occupations that are deemed to be of critical importance to the state. Researchers and policy makes have long worried whether academic institutions will try to capture some of the grant aid that governments provide to help students afford college by raising their tuition levels; to date the empirical evidence on whether this has occurred is ambiguous.

Institutions also provide grant aid to students. Grant aid may be based upon financial need (as at the nation's most selective private colleges and universities) or it may be based upon merit. Merit is broadly defined here to include efforts by institutions to attract students with strong academic or strong athletic backgrounds. For a number of years the National Association of College and University Business Officers (NACUBO) conducted an annual tuition discounting survey to estimate how undergraduate grant aid provided by an institution compared to the tuition revenue that the institution was receiving; recently this survey has been taken over by the College Board. These surveys suggest that the typical private American college or university has a discount rate in the range of 33\%, in the sense that it returns roughly this share of the tuition revenue that it receives back to undergraduate students in the form of grant aid. Of course at the richest private institutions, much of these grant funds come from endowment income.

Increasingly public colleges and universities also provide grant aid to students; in recent years the average tuition discount rate at public four-year institutions was in the range of $15 \%$ of tuition revenues. 


\section{Tuition Keeps Rising in Private Higher Education}

In 1967, William Bowen published an important book that examined what had happened to tuition and fee levels at a set of selective private colleges and universities in the United States during the first two-thirds of the $20^{\text {th }}$ century. He found that, on average, the institutions increased their tuition and fee levels by 2 to 3 percent more than the rate of inflation (as measured by the increase in the Consumer Price Index (CPI)) each year. He attributed this partially to the growth of new knowledge and graduate programs, which added costs to the academic institutions. But first and foremost, he attributed this to the fact that higher education institutions were not sharing in the productivity gains that were occurring in the rest of the economy.

To understand Bowen’s argument, consider a very simple model in which tuition is the only source of revenue for an academic institution and faculty salaries are the only cost for the university. Suppose also that the institution believes that a high quality undergraduate education is dependent upon maintaining a fixed student/faculty ratio. In such a world, faculty members’ productivity does not increase over time; each year they educate the same number of students. However, in the rest of the economy productivity is increasing because of investments in new capital equipment and changes in technology and, since real wages (wages adjusted for inflation) depend upon productivity growth, they too are increasing.

In such a world, the administrators at the academic institution face a dilemma. If they restrict tuition increases to the rate of inflation, salaries of faculty would remain constant (in inflation adjusted terms) and would fall behind the earnings of people in other professional occupations. This would make it difficult to retain existing faculty 
members and to attract new people into graduate study and then faculty positions in academia. Inevitably then, the quality of higher education would decline. Alternatively, the administrators could bite the bullet, raise tuition by more than inflation, and try to keep the salaries of faculty members competitive with salaries in the rest of the economy. The pattern of tuition increases during the first two-thirds of the $20^{\text {th }}$ century suggests that they chose the second option.

As I have documented in Tuition Rising, throughout this period of time, tuition and fees at selective private higher education in the United States did not increase as a share of median family income, because median family income was also increasing more rapidly then inflation because of the growth in labor productivity and the growth in the number of two income earner families in the United States. However, the decade of the 1980s was one of virtually no real income growth in the United States, yet tuition kept increasing throughout this decade at rates greater than the rate of inflation. As a result, while tuition and fees at the typical selective private college and university in the United States was in the range of 30 percent of median family income in 1975, today it is over $50 \%$ of median family income. While the growth in financial aid has caused net tuition to rise by a smaller amount, it too is still much higher today as a share of median family income than it was 30 years ago.

In Tuition Rising I have described in detail the forces that have allowed the selective private colleges and universities to keep increasing their tuition and fees at rates that substantially exceed the rate of increase in the CPI. Here I highlight a few of the more important ones. 
First, the selective private colleges and universities have but one objective; they want to be the very best that they can in every dimension of their activities. They want to have the best instructional and research facilities, attract the best students and faculty, provide the highest quality education and support services, and the like. To do all these things takes money. While they try to diversify their revenue streams (by attracting more annual giving to support current operations, to build the endowment and to finance new construction, and by trying to commercialize their faculty members' research findings), in the absence of any market forces that limit tuition increases, increasing tuition is an easy way to generate increased revenues. After all, the institutions can always price discriminate (and they do); they can use a share of the increased revenue that the generate from a tuition increase to provide more grant aid to students who otherwise would not be able to afford to attend the institution to ensure that the tuition increase does not restrict access.

Each year, the numbers of students who apply to attend these institutions keeps getting larger, while the number of positions in their first year classes students has increased only slightly. These institutions have focused primarily on maintaining or increasing their quality rather than increasing their size (although several are now marginally doing so) and despite their increased tuition and fees, students increasingly flock to them. This has occurred in large part because as the distribution of earnings becomes more disperse in the United States, students and their parents instinctively understand that where one goes to college may matter as much as whether one goes to college. In what has become an increasingly "winner take all” society there is increased pressure on students and their families to, in the words of my colleague Robert Frank "to 
buy the best”. And empirically, with one exception, all empirical research on the topic suggests that students who attend selective private colleges and universities in the United States, which Winston's research indicates, provide the greatest subsidy to their students, are making a rational economic choice; they receive benefits in the form of higher postcollege earnings and increased probability of being admitted to high quality professional and graduate programs than would otherwise be the case. Put simply, as long as long lines of students keep knocking on the doors of these selective private institutions clamoring to gain admission to them, there are no market forces to hold the rate of increase in tuition down at these institutions.

Of course these institutions could try to be socially responsible, improve the efficiency of their operations, and get better by substitution rather than by increasing expenditures. Often they do try to do this, especially in the nonacademic sphere of their operations. However, there are a number of forces that prevent them from doing this in the academic sphere of their operations. One is the system of shared governance that prevails within them that gives faculty members an extraordinary amount of influence over academic decisions. Faculty members are crucial to the reputation of these institutions because they are the creators of new knowledge and the ones who educate undergraduate and graduate students. Because the labor market for faculty at these top institutions is very competitive and top faculty are mobile, administrators strive to keep the faculty happy and often this requires them to make greater expenditures than they otherwise would prefer to do.

Another is the important role that alumni and other external constituents play. Alumni are vital to these institutions because they help to recruit new students, provide 
internship opportunities and summer employment opportunities for existing students, provide job opportunities for graduates, and provide financial support in the form of donations for current operations, endowment and new buildings. However, alumni often have very strong preferences for specific programs (often ones that they were involved with when they were students) and any attempt to cut back the scale of, or eliminate a program, may lead to a threat to withhold contributions or other sources of support for the institution if the action is undertaken. This makes it difficult for administrators to cut any program that an external constituent really cares about.

A third is the role that the annual U.S News \& World Report (USNWR) rankings, which in many respects is now the gold standard in rankings, now plays in American higher education. Empirical research shows that when an institution improves in the rankings, other factors held constant, it attracts more applicants, can be more selective and admit a smaller fraction of these applicants, a greater fraction of the students it admits will enroll at the institution, these enrolled students will have higher test scores, and the institution will be able to spend less on grant aid to attract the students. Conversely, when an institution falls in the rankings, just the reverse occurs. Administrators passionately care about these outcomes and while administrators often claim that they pay no attention to the USNWR rankings and that the rankings do not influence anything that goes on at the university, such statements simply are false.

The formula that USNWR uses to compute its rankings gives positive weight to the educational expenditures per student that an academic institution makes. Hence any academic institution that unilaterally reduced its expenditures per student, or even the rate of growth of its expenditures per student relative to its competitors' rate of growth, would 
find that it would fall in the rankings. Hence, the USNWR rankings methodology does not reward academic institutions for holding their costs down; it puts pressure on the institutions to spend more.

Of course to say that the selective private colleges and universities continue to have long lines of applicants clamoring to gain admission is not to say that most private colleges in the United States face this situation. In fact, many private colleges and universities admit large fractions, if not virtually all, of the individuals that apply to them. Yet these other private colleges and universities, for the most part, have increased their tuitions at roughly the same rates over time as the most selective privates.

They have been able to do this in part because of the belief that in the higher education market, posted price (tuition and fees) is taken by many to be an indicator of quality; if an institution lets its tuition fall relative to its competitors it runs the risk of being perceived as an inferior institution. In part, they have been able to do this because students and their families do not seem to respond in a symmetric fashion to tuition increases and grant aid increases; Christopher Avery and Caroline Hoxby have found that awarding accepted students a merit based grant has a larger effect on their enrollment probabilities than reducing tuition by an equal amount.

Not surprisingly, tuition discount rates tend to be higher at smaller less selective private liberal art colleges than they do at the more selective private liberal art colleges and the private research universities. The more selective an institution is, the less it needs to use grant aid to try to attract students to it. 


\section{Tuition Keeps Rising at Public Institutions}

During the last 30 years, rates of tuition and fee increases at 4-year public higher education institutions in the United States have been equal to or greater than the rates of tuition increases at the 4-year privates. However, while tuition increases at the privates have always been associated with increases in expenditures per student, tuition increases at the publics have often been associated with decreases in expenditures per student. This occurs because in addition to the factors described above that influence tuition growth in private higher education, tuition growth in public higher education is influenced by changes in the state appropriations that public higher education institutions receive. As I describe in The Perfect Storm, tight budgets faced by the states during the period due to several recessions, limitations on the willingness of the public to increase state tax rates, competing demands on state budgets from elementary and secondary education, Medicaid, and the criminal justice system, and large increases in college-age populations, have limited the ability of states to increase their support for their higher education institutions. On a real per student basis, state appropriations per student today are only slightly greater than they were at the start of the period. As a result, tuition has risen and state appropriations have fallen as a share of public college and university budgets in the United States.

Although tuition has risen at roughly the same rate (in recent years roughly $3 \%$ more than the rate of increase in the CPI) at public and private higher education institutions in the United States, because state appropriations have failed to grow at a similar rate, expenditures per student have fallen in public higher education relative to that in private higher education. As a result, faculty salaries in public higher education 
have fallen relative to faculty salaries in private higher education, which makes it more difficult for the public institutions to attract and retain high quality faculty. Student faculty ratios have also risen in public higher education relative to those in private higher education. Great concern has been expressed that these changes are causing a decline in the relative quality of public higher education in the United States.

To try to reduce these financial pressures, public higher education institutions are pursuing a number of strategies. Public colleges and universities have always charged higher tuition and fee levels to students enrolling in their institutions who are not residents of the state in which the institution is located. Many public institutions have substantially increased the dollar gap between what in-state and out-of-state students are charged and, when possible, have sought to increase the share of their students they enroll from out-of-state as a way of generating additional revenues.

A number have moved towards charging differential tuition and fee rates for undergraduate students depending upon the program in which the student is enrolled. Historically, colleges and universities charged the same rate for all students; the notion being that students should be able to choose what to study based upon their intellectual interest, not based on costs. However, financial pressures have led public institutions to begin to charge higher tuition and fees for high cost majors (due to small class sizes or the need for expensive equipment) and/or for majors that promise to lead to jobs with high economic returns. The intellectual justification for such strategies was articulated long ago by Stephen Hoenack and William Weiler. 


\section{Graduate and Professional Program Tuition and Fees}

The discussion above all deals with undergraduate education. American colleges and universities also enroll graduate students in professional degree programs in law (JD), medicine (MD), business and management (MBA) and a host of other fields. They also enroll students in research masters (MA or MS) and PhD programs. Tuition and fees for professional degree programs are often market determined and are often higher than the tuition charged to undergraduate students at the same institution. The higher tuition levels are justified by the high earnings that entry into these professional fields promises to potential students. Students bear the cost of tuition and fees in most professional degree programs, although increasingly professional programs award both need based and merit aid to attract a diverse student body and to improve its academic profile.

In 2007-2008 annual tuition and fees at many top private law, graduate business and medical schools were in the $\$ 40,000$ to $\$ 45,000$ range. With tuition levels this high, many students have extremely large loan burdens upon graduation. To encourage law students to enter low paying public service law careers, many of the selective private law schools have funded their own programs that provide for loan forgiveness if graduates are employed in public service positions for a specified number of years. A recent study by Erica Field looked at an interesting quasi-experiment that the NYU law school conducted. Applicants who expressed interest in entering public law careers were offered either a loan forgiveness program or free tuition, with the understanding that the tuition would have to be paid back if they did not enter public interest law careers upon graduation. The two options were developed to have the identical present value to participants. Field's 
striking finding was that providing tuition remission up front was much more effective in inducing students to enter public interest law careers.

Tuition levels for students enrolled in most $\mathrm{PhD}$ programs are much more similar to undergraduate tuition levels. However, at the best private and public universities very few students actually pay tuition on their own. Because the economic return upon graduating from a PhD program in many fields is relatively low, doctoral programs must provide financial support to doctoral students to induce them to enroll in their programs. This support often comes in the form of a multiyear guarantee, with the support being either a fellowship (no work expectation), a teaching assistantship, or a research assistantship; students often have a variety of these forms of support during the time as doctoral students. Tuition remission and increasingly the provision of health insurance are part of these packages. 


\section{Bibliography}

Avery, C and Hoxby, C. (2004) Do and should financial aid affect students’

college choices? In Hoxby, C. (ed.) College Choices. Chicago IL: University of Chicago Press

Baum, S. and Lapovsky, L. (2006) Tuition discounting: not just a private college practice. New York NY: The College Board

Bowen, W.G. (1967) The economics of the major private research universities. Berkeley CA: Carnegie Commission on Higher Education

Ehrenberg, R.G. (2000) Tuition rising: why college costs so much. Cambridge MA: Harvard University Press

Ehrenberg, R.G. (2006) The perfect storm and the privatization of public higher education, Change 38, 47-53

Field, E. (2006) Educational debt burdens and career choice: evidence from a financial aid experiment at NYU Law School, National Bureau of Economic Research Working Paper No. 12282

Frank, R.H. and Cook, P.J. (1995) The Winner-take-all society. New York NY: The Free Press

Hoenack, S.A. and Weiler, W.C. (1975) Cost-related tuition policies and university enrollments, Journal of Human Resources 10, 332-360

Monks, J. and Ehrenberg, R.G. (1999) U.S News \& World Reports college rankings: why do they matter? Change 31, 42-57e 
Rizzo, M.J., and Ehrenberg, R.G. (2004) Resident and nonresident tuition and enrollment at flagship state universities, In Hoxby, C. (ed.), College choice. Chicago IL: University of Chicago Press

Trends in college pricing 2007 (2007). New York NY: The College Board Winston, G.C. (1999) Subsidies, hierarchies and peers: the awkward economics of higher education, Journal of Economic Perspectives 13, 13-36 


\section{Further Reading}

Brewer, D.J., Eide, E.R., and Ehrenberg, R.G. (1999) Does it pay to attend an elite private college? Cross-cohort evidence on the effects of college type and earnings, Journal of Human Resources 34, 104-123

Dale, S.B. and Krueger, A.B. (2002) Estimating the payoff to attending a more selective college: an application of selection on observables and unobservables, Quarterly Journal of Economics 117, 1491-1527

Ehrenberg, R.G. (ed.) (2004) Governing academia. Ithaca NY: Cornell University Press

Ehrenberg, R.G. (ed.) (2007) What's happening to public higher education? Baltimore MD: Johns Hopkins University Press

Eide, E.R., Brewer, D.J., and Ehrenberg, R.G. (1998) Does it pay to attend an elite private college? Evidence on the effects of undergraduate college quality on graduate school attendance, Economics of Education Review 17, 371-376

Groen, J.A., and White, M.J. (2004) In-state versus out-of-state students: the divergence of interest between public universities and state governments, Journal of Public Economics 88. 1793-1814

Long, B.T. (2004) How do financial aid policies affect colleges? The institutional impact of the Georgia HOPE scholarship, Journal of Human Resources 39, 1045-1066

Singell, L.D. and Stone, J.A. (2007) For whom the pell tolls: the response of university tuition to federal grants-in-aid, Economics of Education Review 26, 285-295 


\section{List of Relevant Websites}

1. The College Board Web Site (www.collegeboard.com ). The reader can download the most recent edition of the College Board's publications Trends in College Pricing and Trends in Student Aid from this site.

2. Cornell Higher Education Research Institute (www.ilr.cornell.edu/cheri ). A large number of conference and working papers dealing with the economics of higher education are available on this site.

3. Grapevine/Center for the Study of Education Policy at Illinois State University (www.grapevine.ilsu.edu ). An annual compilation of state tax appropriations for higher education institutions in the United States.

4. WebCaspar (http://webcaspar.nsf.gov ). A searchable institutional data base that provides annual data on tuition and fees (and many other variables) for all higher education institutions in the United States

5. State Higher Education Executive Officers (SHEEO (www.sheeo.org ). The reader can download its annual "Survey of State Tuition, Fees and Financial Assistance Policies for Public Colleges and Universities) 